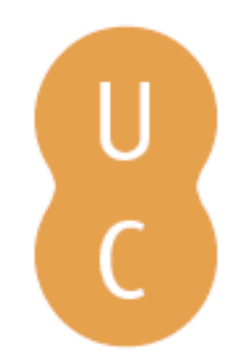

\title{
nommalina
}

\section{Application of holistic ecological indicators of ecosystem's integrity: a case study in the Mondego Estuary}

\author{
Autor(es): $\quad$ Marques, João Carlos; Pardal, Miguel Ângelo; Nielsen, Soren Nors; \\ Jorgensen, Sven Erik
}

Publicado por: Imprensa da Universidade de Coimbra

URL persistente:

URI:http://hdl.handle.net/10316.2/32736

DOI:

DOI:http://dx.doi.org/10.14195/978-989-26-0336-0_37

Accessed : $\quad$ 26-Apr-2023 11:42:38

A navegação consulta e descarregamento dos títulos inseridos nas Bibliotecas Digitais UC Digitalis, UC Pombalina e UC Impactum, pressupõem a aceitação plena e sem reservas dos Termos e Condições de Uso destas Bibliotecas Digitais, disponíveis em https://digitalis.uc.pt/pt-pt/termos.

Conforme exposto nos referidos Termos e Condições de Uso, o descarregamento de títulos de acesso restrito requer uma licença válida de autorização devendo o utilizador aceder ao(s) documento(s) a partir de um endereço de IP da instituição detentora da supramencionada licença.

Ao utilizador é apenas permitido o descarregamento para uso pessoal, pelo que o emprego do(s) título(s) descarregado(s) para outro fim, designadamente comercial, carece de autorização do respetivo autor ou editor da obra.

Na medida em que todas as obras da UC Digitalis se encontram protegidas pelo Código do Direito de Autor e Direitos Conexos e demais legislação aplicável, toda a cópia, parcial ou total, deste documento, nos casos em que é legalmente admitida, deverá conter ou fazer-se acompanhar por este aviso.

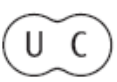


MIGUEL ÂNGELO PARDAL JOÄO CARLOS MARQUES MANUEL AUGUSTO GRAÇA Scientific Editors

\section{Aquatic Ecology of the Mondego River Basin Global Importance of Local Experience}




\author{
MIGUEL ÂNGELO PARDAL \\ JOẢO CARLOS MARQUES \\ MANUEL AUGUSTO GRAÇA \\ Scientific Editors
}

\title{
Aquatic Ecology of the Mondego River Basin Global Importance of Local Experience
}




COORDENAÇÃO EDITORIAL
Imprensa da Universidade de Coimbra
CONCEPÇÃO GRAFICA
António Barros
INFOGRAFIA
António Resende
Estimulus [design] • Coimbra
EXECUÇÃO GRAFICA
GRAFIASA
ILUSTRAÇÃO DA CAPA
P. P. Cunha e ]. Dinis
ISBN
972-8704-04-6
DEPOSITO LEGAL
I75038/02

(C) JANEIRO 2002, IMPRENSA DA UnIVERSIDADE DE COIMBRA

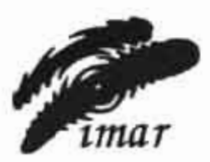

CPIMAR

imar

OBRA PUBLICADA COM O PATROCINIO DE:

IMAR - INSTITUTO DO MAR

IPIMAR - INSTITUTO DE INVESTIGAÇĀO DAS PESCAS E DO MAR 



\author{
joão Carlos marques ' \\ Miguel Ângelo Pardal ' \\ SOREN NORS NIELSEN ${ }^{2}$ \\ SVEN ERIK JøRGENSEN ${ }^{2}$
}

\title{
APPLICATION OF HOLISTIC ECOLOGICAL INDICATORS OF ECOSYSTEM'S INTEGRITY: A CASE STUDY INTHE MONDEGO ESTUARY
}

\begin{abstract}
Benthic eutrophication may cause qualitative changes in marine and estuarine ecosystems, for example the shift in primary producers. Subsequently, changes in species composition and trophic structure at other levels may often occur, and through time a new trophic structure might be selected. In structurally dynamic models such changes may be simulated using goal functions to guide ecosystem behaviour and development. The selection of other species and other food web may then be accounted by a continuous stepwise optimisation of model parameters according to an ecological goal function.

Exergy has been applied as goal function in structurally dynamic models of shallow lakes. Hypothetically, exergy is assumed to become optimised during ecosystems development. Therefore, ecosystems are supposed to self organise towards a state of an optimal exergy configuration. Exergy may then constitute a suitable system-oriented characteristic to express natural tendencies of ecosystems development. and simultaneously a good ecological indicator of ecosystems health.

Biodiversity, a powerful and traditional concept, is also an important characteristic of ecosystems structure. We found it suitable to test the intrinsic ecological significance of exergy. Therefore, we examined the properties of exergy (exergy and specific exergy) and biodiversity (species nchness and heterogeneity) along an estuarine gradient of eutrophication, testing the hypothesis that they would follow the same trends in space and time. This hypothesis was only partially valıdated, since exergy, specific exergy and species richness decreased as a function of increasing eutrophication, but heterogeneity behaved mostly in the opposite way. Nevertheless, exergy and specific exergy behaved as hypothesised, providing useful information regarding the studied communities. They appeared therefore suitable to be used as goal functions in ecological models and as holistic ecological indicators of ecosystem
\end{abstract}

11] IMAR - Instututo do Mar. Centro Interdisciplinar de Coimbra, Departamento de Zoologia, Universidade de Coimbra, 3004-517 Coimbra, Portugal

in Royal Danish School of Pharmacy, Instrtute A. Environmental Chemistry Sertion.

Universitetsparken 2, DK - 2100 Copenhagen 0, Denmark 
integrity. Moreover, since exergy and specific exergy showed to respond differently to ecosystem seasonal dynamics, we recommend using both as complementary parameters.

The method proposed by jørgensen et al. (1995) to estimate exergy, which takes into account the biomass of organisms and the thermodynamic information due to genes, appeared to be operational, but more accurate (discrete) weighting factors to estimate exergy from organisms biomass need to be estimated. We propose to explore the assumption that the dimensions of active genomes, which are primarily a function of the required genetic information to build up an organism, are proportional to the relative contents of DNA in different organisms.

The present contribution was mostly based on two previously published papers (Marques et al. 1997, 1998).

\section{Introduction}

Changes in environmental factors often give origin to qualitative modifications in the ecosystems, such as species composition and biodiversity. For example. eutrophication processes may cause a shift in primary producers, which may also determine changes in species composition at other trophic levels, like the faunal composition. Through time, a sequence of modifications may give rise to the selection of a new structure of the trophic network.

To model these types of qualitative changes, which describe the development of ecosystems as a response to changes in external factors, the qualitative trophic alterations through time must be included in the models. The more conventional deterministic models of aquatic ecosystems, although efficient, due to lack of generality are difficult to apply from one system to another. Nevertheless, it seems possible to incorporate the type of change described above through the development of structurally dynamic models (Jørgensen 1993. Nielsen 1992, 1994, 1995), which has recently been started. The dynamic element of the model is needed to account for the adaptational and selective processes. This new generation of models may improve the existing ones, not only in the sense of increasing their predictive capability, but also by gaining a better understanding of ecosystems behaviour, and consequently providing a better tool for environmental management. In this sense, besides the development of structurally dynamic models, it might be necessary to use soft parameter sets.

552 By applying the principles of optimisation theory in ecology, structurally dynamic models can use goal functions to guide the model simulation of ecosystem behaviour and development (Nielsen 1995), In such a case, in the simulation, the selection of other species and the selection of another food web is accounted for by a change of model parameters according to an ecological goal function. In structurally dynamic models, parameters may be introduced which change as functions of changing forcing functions and conditions of state variables. Therefore. the ability of the ecosystem for instance to move away from thermodynamic equilibrium may be optimised by a stepwise approach. 
In ecological models goal functions are assumed to measure given properties or tendencies of ecosystems, emerging as a result of self-organisation processes in their development. But contrary to what happens in the run of structurally dynamic models, natural ecosystem development and adaptation does not pursue a goal, in the teleological sense. Nevertheless, from an environmentally static assessment point of view, the same mathematical expressions may constitute suitable measures of systemoriented characteristics for natural tendencies of ecosystem development, and good ecological quality indicators. Such measures may then act as an adequate interface between modelling, where they are used in the scope of optimisation theory, and empirical ecology, where they are utilised as environmental indicators.

In the last fifteen years several algorithms have been proposed as possible goal functions. Exergy, a holistic concept derived from thermodynamics Jlorgensen and Mejer 1979, 1981), which can be seen as energy with a built in measure of quality, appears to be a promising approach. Actually, in shallow lake models, exergy exhibited a possible role in expressing shifts in species composition and trophic structure (Jørgensen 1988, Nielsen 1990, 1995).

Hypothetically, exergy is assumed to become optimised during ecosystem development. In other words, ecosystems are supposed to self-organise towards a state where this property is optimised (Jørgensen 1992). There are nevertheless theoretical and practical problems to be solved before this concept can be entirely accepted and used in models for the management of nature and as a holistic ecological quality indicator. Three major questions are empirically approached in this paper:

- What are the relationships between exergy and a more conventional ecological indicator like biodiversity?

- In practice, how can estimations of exergy values be made operational?

- To what extent are estimated exergy values abble to add useful information regarding the state of an ecosystem?

The point in analysing the relationships between exergy and biodiversity was that this latter concept, although somehow illusory, is powerful and intuitive, constituting a good available tool to test the ecological significance of goal functions when describing the ecosystem state. For instance, although there might be other factors involved, it is commonly accepted that, within a given ecosystem, polluted areas (e. g. eutrophied zones), will exhibit less complex communities, with a less complex trophic structure. and lower biodiversity than non polluted areas. Biodiversity may then be considered as an indicator of the quality state of the ecosystem. On the other hand, in what way could exergy, as a holistic ecological quality indicator, be effective in disceming between distinct states of the ecosystem when differences are relatively subtle? We empirically tested the following hypothesis: exergy and biodiversity will follow the same trends in space and time along an estuarine gradient of eutrophication. The chosen study site was the Mondego estuary, in the western Atlantic coast of Portugal (Fig. 1).

The present contribution was mostly based on two papers previously published (Marques et al. 1997, 1998). 


\section{Materials and Methods}

The benthic communities in the Mondego estuary were monitored fortnightly, from February 1993 to February 1994. Samples of macrophytes, macroalgae, and associated macrofauna were collected fortnightly at different sites, during low tide. The organisms were almost always identified to the species level, and their biomass was determined ( $g \cdot \mathrm{m}^{2}$ afdw). Corresponding to each biological sample. the following environmental factors were determined: salinity $\left(g . \mathrm{f}^{-1}\right)$, temperature $\left({ }^{\circ} \mathrm{C}\right), \mathrm{pH}$, dissolved oxygen, ammonia, silica, chlorophyll a, nitrites, nitrates, and phosphates (mg.l'), for the water. and organic matter contents (g.m.2 afdw). for the sediments.

Sampling was performed along a gradient of eutrophication in the south arm of the estuary (Fig. I), from a non-eutrophied zone up to a heavily eutrophied zone, in the inner areas of the estuary. A Zostera noltii community is present in the noneutrophied zone and blooms of the green macroalgae Enteromorpha spp. have been observed during the last decade in the heavily eutrophied zone. The pattern in the most eutrophied zone is that. Enteromorpho spp. biomass normally increases from mid winter to early summer, when an algae crash usually occurs. A second but much less important algae biomass peak may be observed in late summer followed by a decrease in biomass through the fall season.

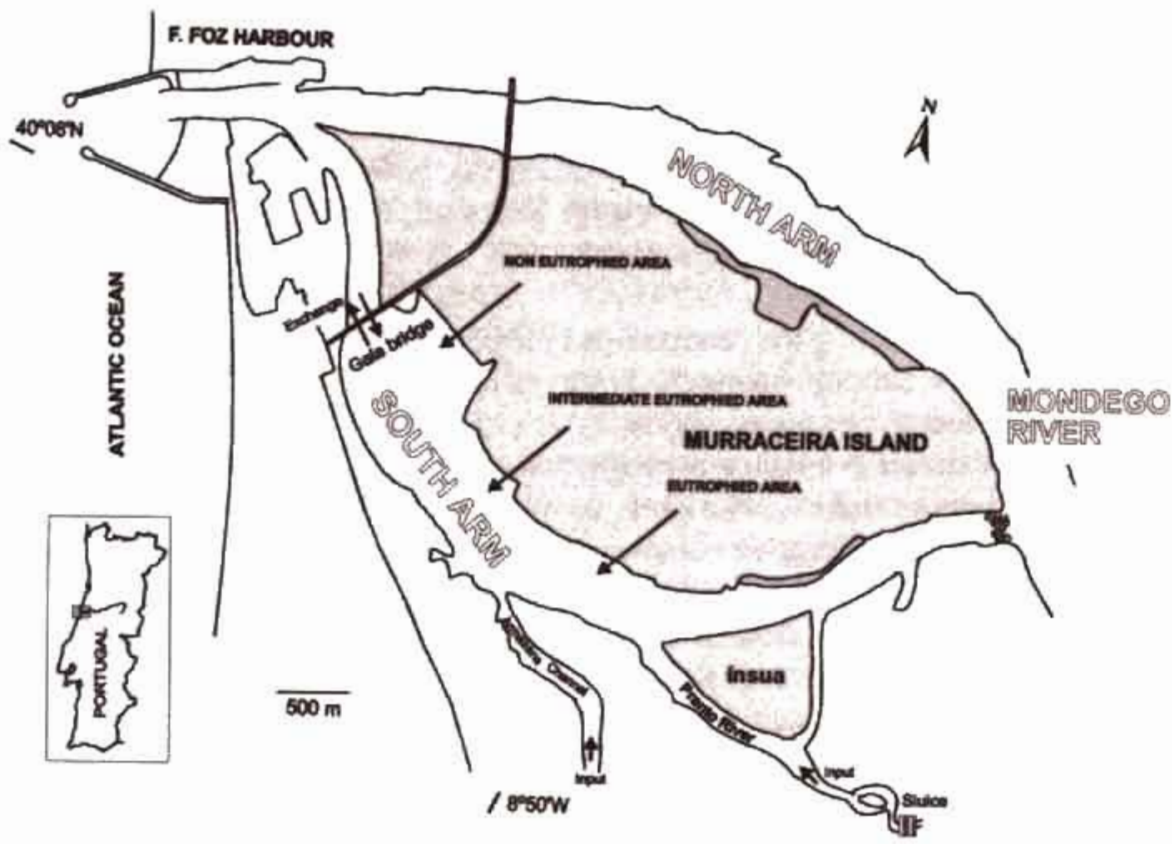

Figure 1, The Mondego estuary: it consists of two arms, north and south, with very different hydrographic characteristics. The southern arm of the estuary is eutrophied, and the gradient of eutrophication is indicated. 
These measurements provided a comprehensive field data set on the spatial and temporal variation of benthic communities along the gradient of eutrophication, and was used to make exergy and biodiversity calculations.

To estimate exergy we used the method based upon the thermodynamic information due to genes proposed by førgensen et al. (1995). This method is considered the best candidate for exergy calculations of ecosystems, because it takes into account the organisational level of the organisms. Following this approach, an estimation of exergy may be given by

$$
E x=T \sum_{i=1}^{i=n} \beta i \cdot C i
$$

where $\mathrm{T}$ is the absolute temperature in Kelvin, $\mathrm{Cl}$ is the concentration of component $\mathrm{i}$ in the ecosystem (e.g. biomass of a given taxonomic or functional group), Bi is a factor which roughly express the quantity of information embedded in the biomass. Detritus is chosen as the reference level, i.e. $\mathrm{Bi}=1$, and exergy in the biomass of different types of organisms is expressed in detritus energy equivalents.

Consequently, the variation of exergy through time in an ecosystem may be caused from the variation of the biomass and information built in one unit of biomass (expressing the quality of the biomass)

$$
\Delta \mathrm{EX}_{\text {wot }}=\Delta \mathrm{B}_{\text {bom }} B i+\Delta B i B_{\text {wom }}
$$

If the total biomass (Biomtot) in the system remains constant through time, then the variation of exergy (Exta) will be a function of only the structural complexity of the biomass or, in other words, of the information embedded in the biomass. It may then be called specific exergy ( $\mathrm{SpEx}$ ), expressed as exergy per unit of biomass. For each instant, specific exergy is given by

$$
\mathrm{SpEx}=\mathrm{Ex}_{\text {toot }} / \text { Biomitot }
$$

Values of exergy and specific exergy were calculated from the biomass of the different organisms ( $g \cdot \mathrm{m}^{-2} \mathrm{afdw}$ ) through the use of weighting factors that are able to discriminate different "qualities" of biomass (Table 1). For this purpose, taking into account the available set of weighting factors, data on organisms biomass was pooled as a function of higher taxonomic levels (e. g. Phylum or Class).

There is nevertheless an obviously lack of discriminating power in the weighting factors given in table 1 . The need for more discriminating weighting factors have in fact been discussed (Marques et al, 1997) and new methodologies have been proposed to allow an easier estimation of weighting factors for different types of organisms (Marques et al. 1997. Fonseca et al. 2000). This involves nevertheless difficulties that are not fully understood and overstepped (Fonseca et al. 2000). 
Table 1. The evolution of $g$ DNAVcell, number of genes, and number of cell types (approximate figures are given) for different organisms. The concentration of each organism was multiplied by the proposed weighting factor to estimate exergy. The weighting factor accounts for the information embodied in the organism in addition to the simple biomass ( $\mathrm{g} \mathrm{m}^{-2} \mathrm{afdw}$ ). For this purpose, it is assumed that detritus (organic matter contents in sediments) does not contain relevant structural information. Sources: $L i$ and Graver (1991) in Jorgensen et al. (1995). All the values marked with * were not provided by any source but assumed as reasonable at the present state of knowledge, taking into account the evolutionary level of the groups concerned.

\section{Organisms}

\section{Detritus}

Bacteria

Algae

Yeast

Fungus

Sponges

Plants, trees

Jellyfish

Nemertineans

Insects

Crustaceans

Annelid worms

Molluscs

Echinoderms

Fish

Birds

Amphibians

Reptiles

Mammals

Human

\section{$10-12 \mathrm{~g}$ DNA/cell}

0
0.005
0.009
0.02
0.03
0.1

0.9

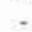

20

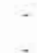

20
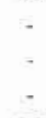

50

90

\section{Number of genes}

0
600
850
2000
3000
9000
$10000-30000$
50000
-
-
100000
-
-
$100000-120000$
120000
120000
120000
140000
250000

\section{Number of cell types}

0
1.2
6.8
5.7
$6-7$
$12-15$
23
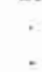

60

60

-

70

-

$\therefore$

100

254

\section{Weighing factor}

1
2.7
3.4
5.8
9.5
$26.7^{\circ}$
30 to $90^{\circ}$
$144^{\circ}$
$144^{\circ}$
$144^{\circ}$
$144^{\circ}$
$287^{\circ}$
$287^{\circ}$
$144^{\circ}$
$287^{-}-344$
$344^{\circ}$
344
344
402
716

Regarding biodiversity, we took into consideration the species richness and the heterogeneity (species richness + eveness). For each date measurements were calculated using data on the species biomass ( $\left.\mathrm{g}_{\mathrm{m}} \mathrm{m}^{-2} \mathrm{afdw}\right)$. For this purpose only macrofauna was taken into account. From the considerable assortment of indices designed by ecologists. we considered suitable the use of the Margalef index (I), to compute species richness, and of Shannon-Wiener's index $\left(H^{\prime}\right)$ based on the information theory, to compute heterogeneity (Legendre and Legendre 1984. Magurran 1988). The Margalef index is:

$$
I=(n-1) / \log _{e} N
$$

where $n$ is the number of species found and $N$ is the total number of individuals, and the Shannon-Wiener index is given by:

$$
H=\sum_{i=1}^{n} p_{i} \log p_{i}
$$


where $n$ is the number of species, and pi is the proportion of the biomass of species $i$ in a community were the species proportions are $p_{1}, p_{2}, p_{3}, \ldots p_{1} \ldots p_{n}$.

Exergy and biodiversity values constitute static estimations of dynamic qualities of ecosystems. Therefore, to examine their properties as ecological indicators, a moving average (using the contiguously prior, present, and following dates) was applied to each value, in order to adjust potential bias due to sampling.

\section{Results - Testing the Working Hypothesis}

The spatial and temporal variation of exergy, specific exergy, species richness, and heterogeneity were analysed, to test the hypothesis that these ecological indicators would capture changes in benthic communities in such a way that they would provide equivalent information about the ecosystem.

Exergy (Fig. 2 A), as hypothesised, was found to be consistently higher in the Zostera noltii community than in the eutrophied areas. Additionally, during the spring and early summer of 1993, exergy values were higher in the most heavily eutrophied area when compared with the intermediate eutrophied area. This was obviously related with the intensity of the Enteromorpha bloom, determining much higher values for total biomass in the most eutrophied area (Fig. 2 C).

Specific exergy was also conșistently higher in the Zostera noltii community than in the eutrophied areas until late spring (Fig. 2 B), in accordance with the working hypothesis. However, the picture changed completely from early summer. when values became higher in the eutrophied areas. This was obviously a function of the macroalgae crash in the eutrophied areas (between the 22 of June and the 6 of July 1993). which resulted not only on a drastic reduction of the total biomass (Fig, 2 C), but also on a change from a primary production based system toward a detritus based food web. Since total biomass after the 6 of July consisted essentially of animals (consumers). primanly deposit feeders and detritic feeders (e. g. annelid worms and crustaceans), it is clear that the abrupt increase of specific exergy in the eutrophied areas after the algae crash does not reflect an augmentation of the structural complexity of the community, but simply the different quality of the biomass involved in the calculations. This becomes evident if we compare the specific exergy estimated for the non eutrophied area (Zostera community), taking only the macrofauna into account, with the values found for eutrophied areas (Fig. 2 B). In fact, after the 6 of July, if we account for both primary producers and consumers, specific exergy is lower in the Zostera community than in the eutrophied areas. But if we account only for the consumers the specific exergy is clearly higher in the Zostera community, following the same pattern from before the algae crash, in agreement with the working hypothesis. We must conclude that the specific exergy may shift very drastically as a function of annual dynamics, like in communities dominated by $r$ strategists, providing spatial and temporai information that may not be related with the long-term evolution and integrity of the system. 

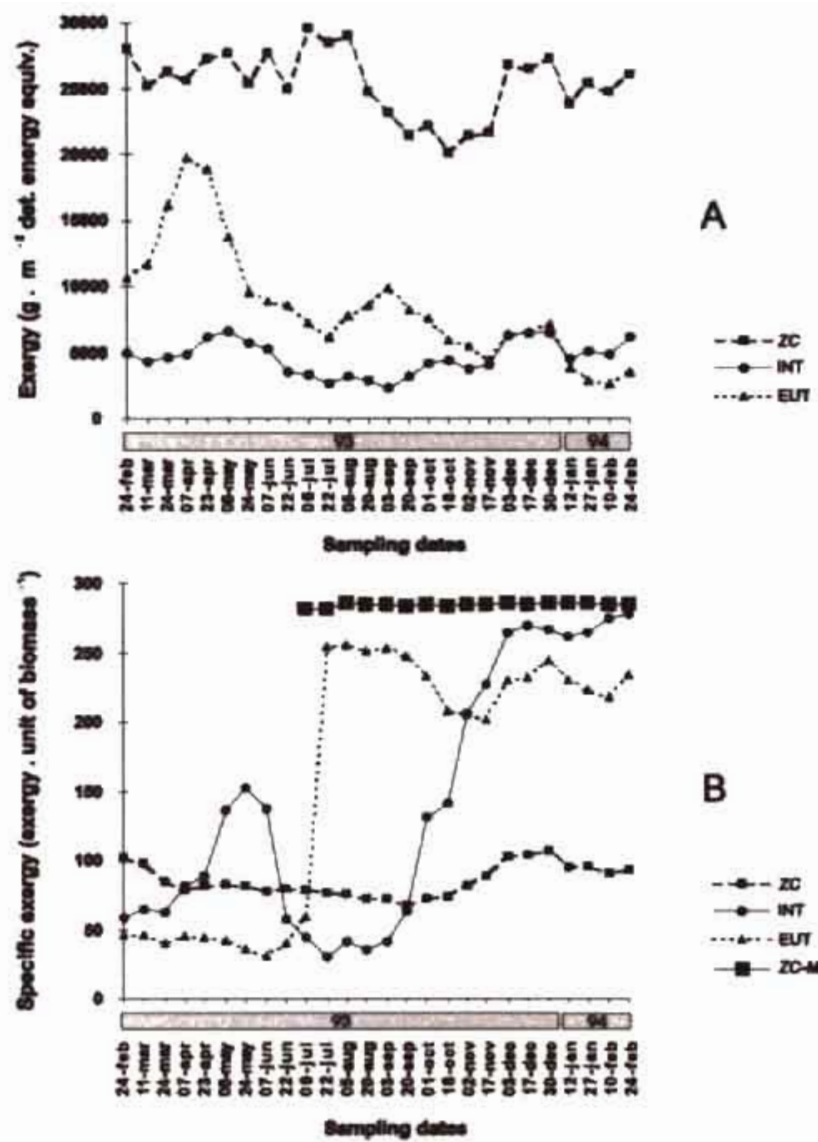

B
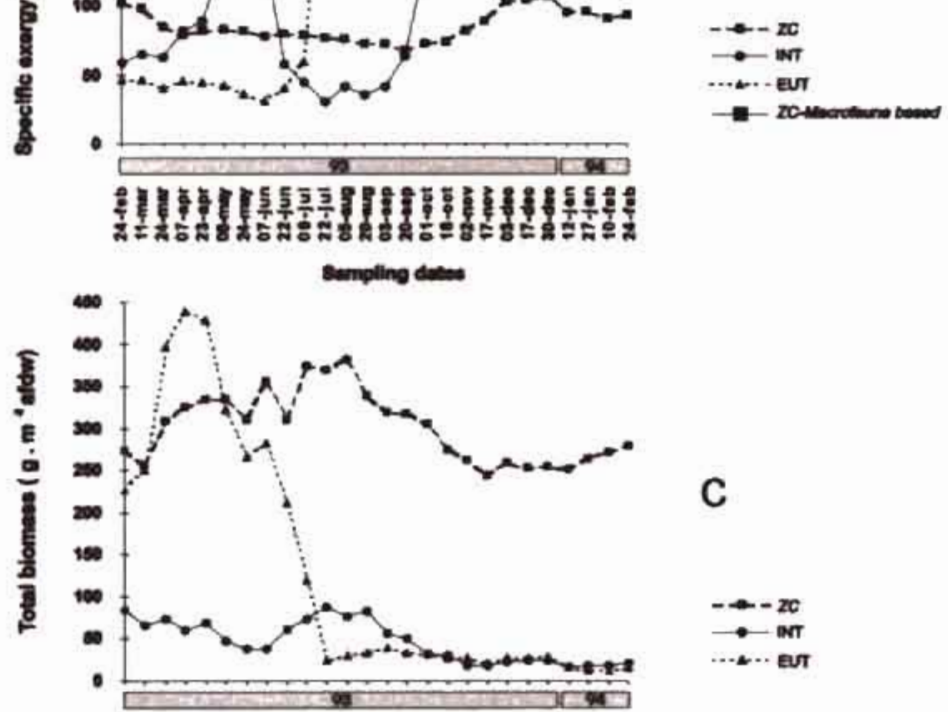

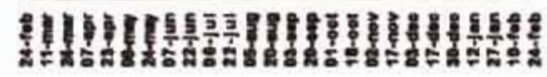

Sampling dates

Figure 2. Spatial and temporal variation of exergy (A) specific exergy (B). and total biomass (C) in non eutrophied (Zostera nolti community) (ZC), intermediate eutrophied (INT) and eutrophied (EUT) areas. For specific exergy (B), we indicate the values estimated from the total bıomass, taking into account the whole period, and the values estimated only from the macrofaunal biomass, for the period from 6 of July 1993 to 24 February 1994. 
The variation of species richness and heterogeneity (species richness + eveness) along the gradient of eutrophication provided quite different information (Fig. 3). Through time, as hypothesised, species richness was consistently higher in the noneutrophied area, corresponding to the Zostera community, decreasing along the gradient of eutrophication (Fig, 3 A). On the contrary, heterogeneity was always higher in the eutrophied areas (Fig. 3 B). The only exception was the decrease observed in the most heavily eutrophied area in early summer, which was related with the algae crash causing a drastic reduction of total biomass (Fig. $2 \mathrm{C}$ ).

The observed spatial variation of heterogeneity was not in agreement with the working hypothesis. This originates in the fact that the Shannon-Wiener's index integrates two components, the number of species (species richness) and their relative abundances (evenness). As expected, species richness decreased as a function of increasing eutrophication, but the extremely high concentration (dominance) of a few species in the Zostera community, namely Hydrobia ulvae, a detritic feeder and epiphytic grazer gastropod, and Cerostoderma edule, a filter feeder bivalve, decreased species eveness, and consequently heterogeneity values. In this case, lower values of heterogeneity must be interpreted as expressing higher biological activity of these species, probably due to the abundance of nutritional resources in the Zostera community, and not as a result of environmental stress (Legendre and Legendre 1984).

To what extent did exergy and biodiversity follow the same trends in space and time, as hypothesised, decreasing from non-eutrophied to eutrophied areas? Taking into account the whole year data set, the variation of exergy and specific exergy along the eutrophication gradient (non eutrophied, intermediate eutrophied, and eutrophied areas) was significantly correlated ( $P \leq 0.05$ ) (Fig. 4 A), providing an equivalent information from the system. Values were consistently higher and more stable in the non-eutrophied area as compared to the eutrophied ones. Moreover, through the comparison of yearly exergy data series for each site ( $t$ test, $P \leq 0.05$ ) it was possible to distinguish between the three situations. However, for specific exergy, differences between the intermediate eutrophied and eutrophied areas were not significant, which suggests that exergy might be more sensitive to detect subtle differences.

Species richness and exergy appeared significantly correlated ( $P \leq 0.05)$, following a similar spatial pattern, both decreasing from non-eutrophied to eutrophied areas (Fig. 4 B). On the contrary, heterogeneity and exergy appeared to be negatively, although not significantly correlated (Fig. 4 A), providing totally diverse information of the benthic communities along the eutrophication gradient. As explained above, this resulted from the properties of the heterogeneity measure.

Different results were obtained comparing the patterns of variation of species richness, heterogeneity and specific exergy. Species richness and specific exergy appeared clearly positively correlated ( $P \leq 0.05$ ) (Fig. 4 B), while the patterns of variation of heterogeneity and specific exergy were distinct (Fig. 4 A). Moreover, from the comparison of yearly data series ( $t$ test. $P \leq 0.05$ ), heterogeneity values were not significantly different between the intermediate eutrophied and eutrophied areas, and therefore did not permit to discriminate the existing differences. 

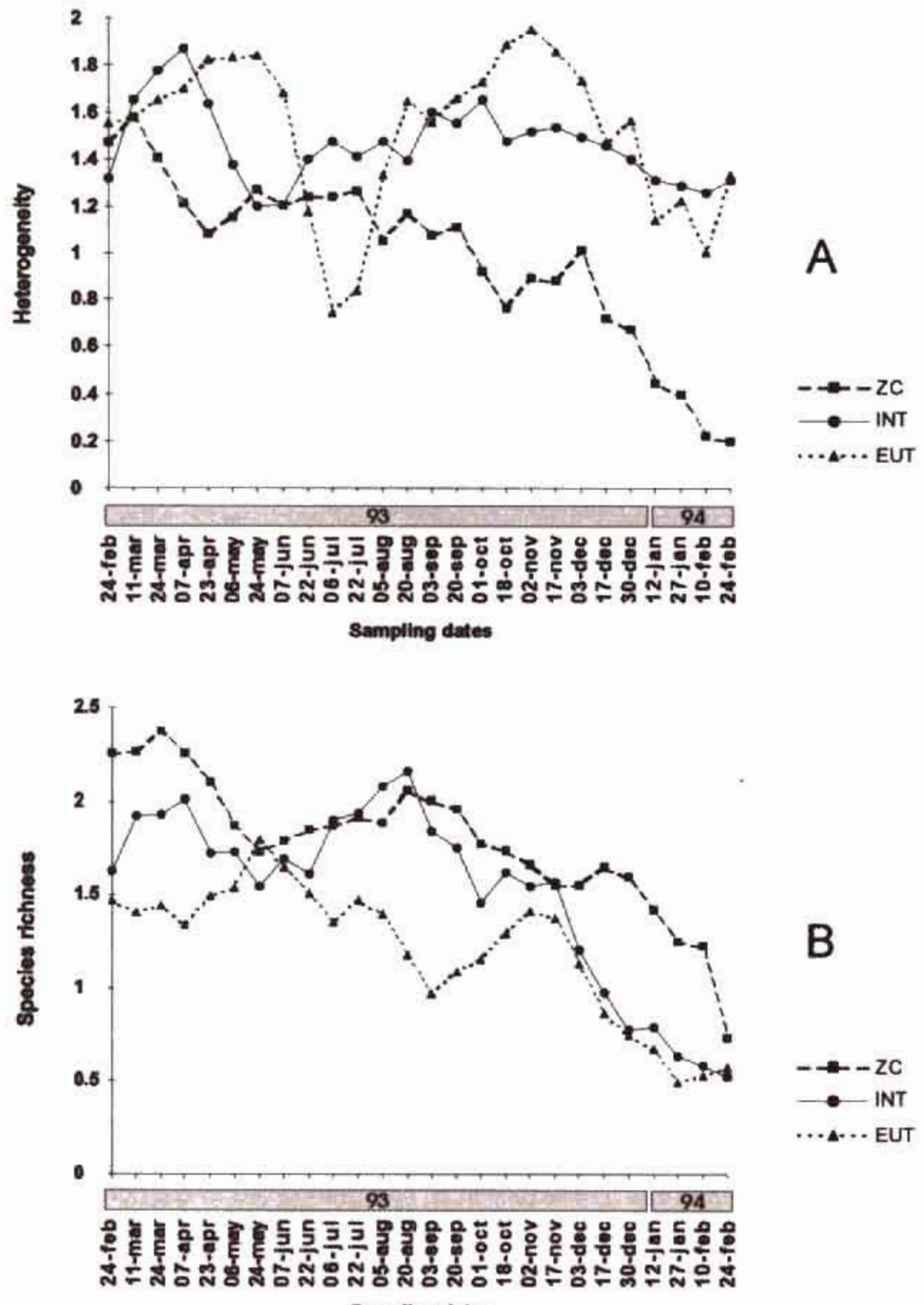

Figure 3. Spatial and temporal variation of heterogeneity (A), species richness (B) in non eutrophied ( $\mathrm{ZC})$. intermediate eutrophied (INC) and eutrophied (EUT) areas. Hieterogeneity was computed using the Shannon-Wiener's index, and species richness using the Margalef's index. 

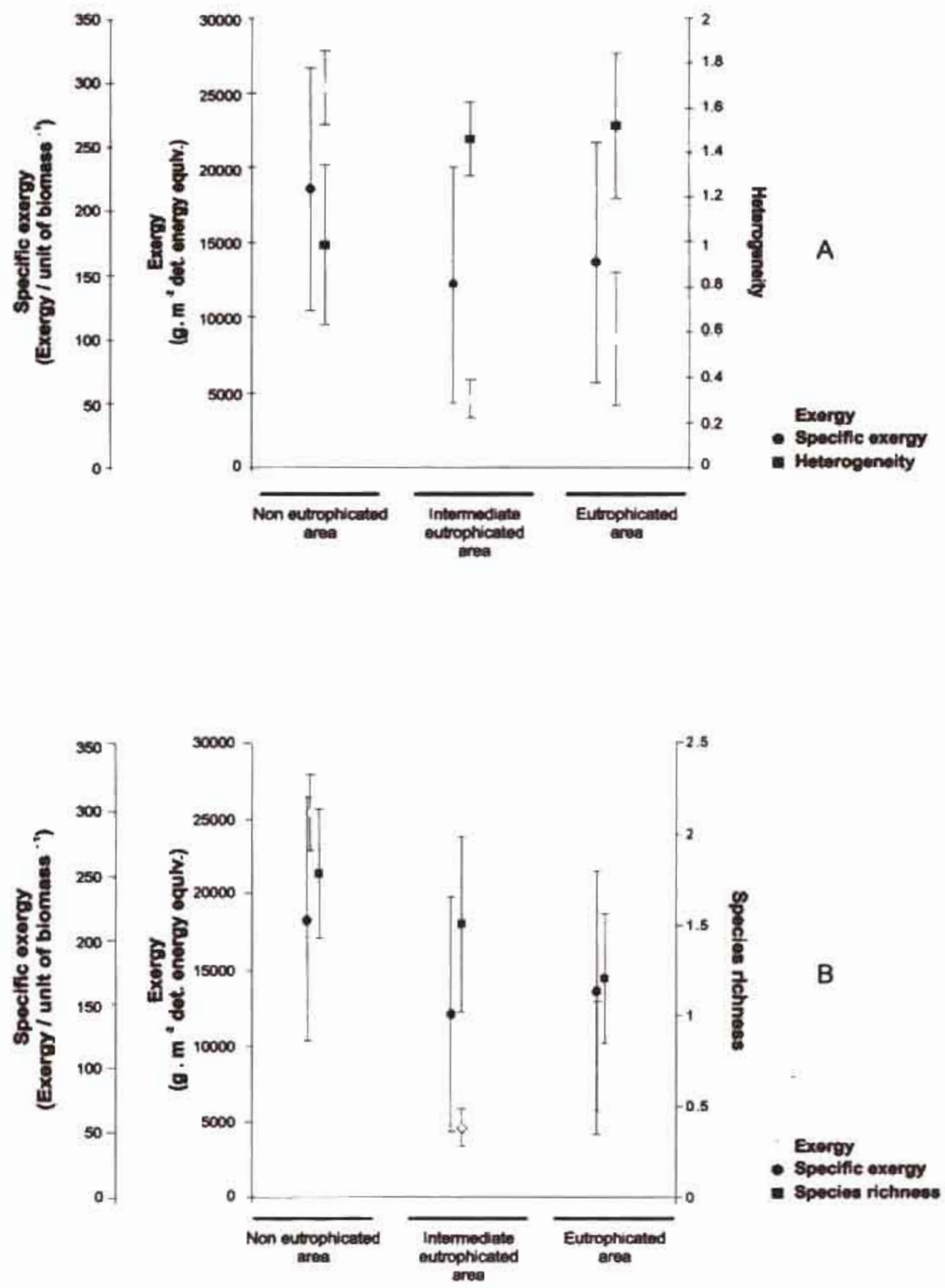

Figure 4. Variation of exergy and specific exergy in comparison with heterogeneity (A) and species richness $(B)$ along the gradient of eutrophication gradient. For each situation, respectively non eutrophied (ZC). intermediate eutrophied (INT), and eutrophred (EUT), we indicate the average values and the standard deviation. taking into account the entire yearly data set. The spatial variation of exergy and specific exergy was significantly correlated ( $r=0.59 ; P \leq 0.05)$. The spatial variation of heterogeneity was not significantly correlated nerther with exergy or specific exergy ( $r=-0.48$ and $r=0.38$ respectively, PS 0.05). The spatial vanation of species richness was significantly correlated with both exergy and specific exergy $(r=0.60$ and $r=0.90$ respectively. $P \leq 0.05$ ) 


\section{Discussion and Conclusions}

The hypothesis that exergy and biodiversity would follow the same trends in space and time was validated with regard to species richness, but not for heterogeneity. In fact. exergy, specific exergy, and species richness responded as hypothesised. decreasing from non-eutrophied to eutrophied areas, but heterogeneity responded in the opposite way, showing the lowest values in the non-eutrophied area. On the other hand, exergy and species richness were able to grade situations presenting relatively subtle differences, but specific exergy and heterogeneity appeared to be less sensitive. Moreover, as ecological indicator, heterogeneity (measured using the ShannonWiener's index) appeared to be a more subjective interpretation. Exergy and specific exergy appeared to be able to provide useful information regarding the state of the benthic communities, and might therefore constitute suitable system-oriented characteristics, and may be good indicators of ecosystem integrity. Since specific exergy may shift drastically as a function of annual dynamics, it provides spatial and temporal information, which is different from static exergy measures. Therefore, we recommend using exergy and specific exergy as complementary parameters.

The method proposed by Jørgensen et al. (1995) to estimate exergy, which takes into account both biomass and the thermodynamic information due to genes, appears to be operational, but more accurate (discrete) weighting factors to estimate exergy from organisms biomass need to be determined (Table I). Moreover, using the number of genes to express the thermodynamic information built in the biomass is not practical because genetic mapping available in published data is very scarce. Actually, most of the organisms in biotic systems have not been characterised owing to the long time procedures and high costs involved in the molecular work of gene analysis. Therefore, it was proposed to undertake a more practical approach (Marques et al. 1997. 1998, Fonseca et al. 2000).

The dimension of the active genome is primarily a function of the required genetic information to build up an organism. Since this genetic information is contained in DNA, it is reasonable to assume that the dimension of each active genome is roughly proportional to the contents of DNA in the nucleus of diploid cells of each organism. These contents may be determined through the isolation, purification, and analysis of cell nucleus from representative organisms. Obviously, in a certain extent, data produced will not be so accurate as data provided by genetic analysis, but this will not be a problem since the aim is to generate conceptual exergistic relationships between different kinds of organisms. In this case, their complexity will be accounted as an

562 indirect measure of the quality (thermodynamic information) of the biomass, proportional to the distance of that matter to thermodynamic equilibrium. 


\section{References}

Fonseca. I. C. J. C. Marques, A. A. Paiva. A. M. Freitas. V. M. C. Maderra and S. E. Jergensen. 2000, Nuclear DNA in the determination of weighing factors to estimate exergy from organusms biomass. Ecol. Model 126 179-189.

jorgensen. S.E. 1988. Use of models to account for changes in species composition. Ecol. Model. 41:117-126 lørgensen. S. E. 1992. Integration of Ecosystem Theones: A Pattern. Kluwer Academic Publishers. 383 p

Jergensen, S. E. 1993. State of the art of ecological modeling. In: McAleer M (ed) Proceedings of the International Congress on Modelling and Simulation, University of Western Australia, pp 455-481.

jorgensen, S. E. and Mejer, H. 1979. A holistic approach to ecological modelling. Ecol. Modei. 7: 169-189

jargensen, S. E. and Mejer. H. 1981. Exergy as a key function in ecological models. In: Mitsch W, Bosserman RW, KJopatek JM (eds) Energy and Ecological Modelling. Developments in Environmental Modelling, vol 1. Elsevier, Ansterdam, pp 587-590.

lergensen. S. E., Nielsen, S. N. and Mejer, H. 1995. Emergy, envron. exergy and ecological modelling, Ecol. Model. 77: 99.109.

Legendre. L and Legendre. P. 1984. Ecologie numénque I - Le traitement muitiple des données écologiques. Masson, Paris. pp 1-197.

Magurran, A. E. 1988. Ecological diversity and its measurement. Croom Helm, London

Marques. L. C. M.A. Pardal, S. N. Nielsen and S. E. jørgensen, 1997. Analysus of the properties of exergy and biodiversity along an estuarine gradient of eutrophication. Ecol. Model, 102:155-167.

Marques.J. C. M. A. Pardal S. N. Nielsen and S. E. jørgensen, 1998. Thermodynamic Onentors: Exergy as a holistic ecosystem indicator: A case study. In Müller, F. and Leupelt, M. (eds) Ecotargets, goal functions. and onentors. Theoretical concepts and interdisciplinary fundamentals for an integrated, system-based environmental management. Chapter 2.5: 87 - 101. Springer.Verlag, Berlim.

Nielsen, S. N., 1990. Application of exergy in structural dynamic modelling. Verh Int Verein Limnol 24:641. 645.

Nielsen, S. N.. 1992. Strategies for structural dynamic modelling. Ecol. Model. 63: 91-101.

Nielsen. S. N. 1994. Modelling structural dynamical changes in a Dantsh shallow lake. Ecol. Model. 73: 13-30.

Nielsen. S. N.. 1995. Optimisation of exergy in a structural dynamic model. Ecol. Model. 77: 111 - 122 
Série

Investigação

$\bullet$

Coimbra

Imprensa da Universidade

2002 